\title{
COST OF LOANS TO BORROWERS UNDER UNREGULATED LENDING
}

\author{
WiLLiAM Hays Simpson*
}

While many individuals think in terms of 5 to $10 \%$ per annum in the extending. and the receiving of monetary loans, thousands of persons today experience the pain of paying roo, 200, 300\% and over per annum for small loans. This is true in about a score of states where unregulated lenders are not only permitted to carry on a lucrative business but are aided by the laws-laws which do not afford opportunities for legitimate small loan companies to function satisfactorily in the states. In collecting more than two thousand case histories of borrowers in North and South Carolina the writer has had opportunity to observe at first hand the charges being made in these unregulated states. The exorbitant rates charged in South Carolina are revealed in an investigation completed by the writer in September, 1939, for the Women's Council for the Common Good of South Carolina. In this study, as also in a subsequent one of North Carolina, any compensation paid to the lender for the use of money was considered interest whether it was regularly called by the lender, for example, investigation fee, entry or brokerage fee.

As a minimum charge of one dollar in lieu of interest may be legally made in South Carolina, a number of loan companies operate under a dollar discount plan, specializing in lending small sums of money for a short period of time. Borrowers have paid $\$ \mathrm{I}$ for the use of $\$ 5$ for one week, but usually duration of the loan is established for two weeks. Under the more liberal plan the borrower pays an annual rate of $520 \%$. Many negotiated loans require repayment in installments. For example, \$1o loans are payable at the rate of $\$ 2.40$ a week for 6 weeks or, as in other instances, $\$ \mathrm{r} .20$ a week for I2 weeks. The annual interest rate, computed according to the "constant ratio" formula, is slightly over $653 \%$ in the former plan and $352 \%$ in the latter.

Of the 1,042 borrowers interviewed in South Carolina, more than one half were employed in cotton mills, others worked for laundries, dry cleaning establishments, hotels, lumber yards, express companies, municipalities, railroads and other places. Only three borrowers were unemployed and they represent unusual cases. The fol-

- A.B., 1926, Tusculum College; M.A., 1928, Ph.D., 1935, Duke University. Instructor of Political Science, Duke University. Contributor to legal periodicals. Author, The Small Loan Problem in South Carolina (1940).

${ }^{1}$ Mergendahl and Foster, One Hundred Problems in Consumer Credit (Pollak Foundation, 1937) Pamphlet No. 35. 
lowing table, therefore, represents the cost of small loans to wage earners. It shows the average annual rates charged on 1,042 loans made to both white persons and Negroes in 14 towns and cities of South Carolina. These rates are classified first on the basis of amount of the loans and, second, on the basis of the race of the borrower. ${ }^{2}$

\section{Table I-South Carolina}

Average Annual Interest Rates Paid on Loans of Different Sizes By White and Negro Borrowers Interviewed in South Carolina Towns and Cities, 1938, 1939.

\begin{tabular}{|c|c|c|c|c|c|c|c|c|}
\hline \multirow[b]{2}{*}{ Locality } & \multicolumn{4}{|c|}{$\begin{array}{c}\text { When louns to Whites were of the } \\
\text { specified amounts }\end{array}$} & \multicolumn{4}{|c|}{$\begin{array}{c}\text { When loans to Negroes twere of the } \\
\text { specified amounts }\end{array}$} \\
\hline & $\begin{array}{l}\$ 10.00 \\
\text { or less }\end{array}$ & $\begin{array}{l}\$ 10.01- \\
\$ 25.00\end{array}$ & $\begin{array}{l}\$ 25.07- \\
\$ 50.00\end{array}$ & $\begin{array}{l}\text { Above } \\
\$ 50.00\end{array}$ & $\begin{array}{l}\$ 10.00 \\
\text { orless }\end{array}$ & $\begin{array}{l}\$ 10.01- \\
\$ 25.00\end{array}$ & $\begin{array}{l}\$ 25.01 \\
\$ 50.00\end{array}$ & $\begin{array}{l}\text { Aboute } \\
\$ 50.00\end{array}$ \\
\hline $\begin{array}{l}\text { Anderson } \\
\text { Charleston }\end{array}$ & $\begin{array}{l}373.33 \\
356.13\end{array}$ & $\begin{array}{l}3^{62.39} \\
286.85\end{array}$ & $\begin{array}{l}208.38 \\
216.00\end{array}$ & $\overline{242.42^{*}}$ & $\begin{array}{l}432.57 \\
955.20\end{array}$ & 286.14 & & \\
\hline Columbia & 377.47 & 275.46 & $1147.14 *$ & & $3^{86.55}$ & 349.25 & $680.00 *$ & \\
\hline Florence . & 417.55 & 212.93 & 157.73 & & 322.24 & 267.82 & $64 \cdot 30$ & $46.96^{\circ}$ \\
\hline Greenville & 383.69 & $255.7^{\circ}$ & 151.88 & 98.99 & 595.67 & & & \\
\hline Rock Hill .. & 598.54 & & & & 755.13 & 523.13 & & \\
\hline Spartanburg & 396.06 & 298.15 & 248.99 & 105.39 & 551.68 & $353.4 x$ & $99.05^{*}$ & \\
\hline $\begin{array}{l}\text { Sumter } \ldots \ldots \\
\text { Clinton }\end{array}$ & 278.64 & 224.14 & $4^{0.56}$ & & $355.5^{\circ}$ & 198.39 & & \\
\hline $\left.\begin{array}{l}\text { Greenwood } \\
\text { Newberry }\end{array}\right\}$ & 394.12 & 290.08 & 195.76 & $\longrightarrow$ & 630.72 & 184.17 & & \\
\hline $\left.\begin{array}{l}\text { Hartsville } \\
\text { Darlington } \\
\text { Orangeburg }\end{array}\right\}$. & $55^{8.74}$ & 297.79 & 159.63 & 29.49 & 522.90 & $183: 50$ & 99.25 & \\
\hline
\end{tabular}

- Percentage based on an insufficient number of loans to be representative.

It may be noted from the foregoing table that with an increase in the size of the loan, there is in general a decrease in the rate charged. This is due largely to the fact that the loans in the highest brackets are more selective and have much better security.

Neither the treatment extended the borrowers nor the conditions relative to the loans were identical in the 1,042 cases. Perhaps a few examples will serve as illustrations.

(1) One borrower, a white married man whose salary is $\$ 35$ a week, has worked for his present employer for 27 years. His wife's prolonged sickness necessitated the borrowing of $\$ 83$ from four different loan companies in the amounts of. $\$ 25, \$ 30$, $\$ 18$ and \$10. The four loan companies charged this borrower $\$ 16$ a month for the use of this money, and at the end of a year he still owed the $\$ 8_{3}$ but had paid the loan companies $\$ 192$ in interest. A friend finally came to his assistance and retired the loans.

(2) Another borrower, an employee of a lumber yard, with a salary of $\$ 10$ a week and a wife and three children to support borrowed $\$ 8$ to pay his house rent. He paid the loan company $\$ 3.75$ a week for three weeks and at the end of each of the

"Sec Simpson, The Small Loin Problem in South Carolint (1940) it. 
three succeeding weeks he paid $\$ 1.50, \$ 2$ and $\$ 1.50$ respectively. In spite of having paid $\$ 16.25$ in six weeks on an $\$ 8$ loan, the loan company requested $\$ 1.50$ more from the borrower. The victim appealed to his white employer who readily supported his employee in refusing to pay the $\$ 1.50$.

(3) A third borrower, who had worked for a railroad for three years at a salary of \$ro a week, desired to buy his daughter a wedding present. He offered a wage assignment as security and was extended a loan of $\$ 5$. The loan, however, was discounted 84 cents and the borrower was required to repay the loan the following day. The annual interest rate on this loan was over $7,300 \%$.

Although not nearly as numerous as in South Carolina, high-rate loan companies enjoy a flourishing business in North Carolina. The rates are somewhat lower. Occasionally a dollar interest charge is made on a $\$ 5$ loan for 30 days; an annual rate of $240 \%$. Usually, however, it is required that the $\$ 5$ be repaid in four weekly installments of $\$ 1.50$ each. Under this plan the annual rate is $416 \%$. When $\$$ ro loans are repaid according to agreement in installments of $\$ 1.65$ a week for eight weeks or $\$ 2.40$ every two weeks for 12 weeks the rate is approximately $369 \%$ and $326 \%$ respectively.

The 200 borrowers interviewed in North Carolina during the past summer were employees of cotton and hosiery mills, laundries and municipalities. The following table shows the annual rates charged on 200 loans to both white persons and Negroes. The rates are classified on the basis of the amount of the loan and the race of the borrower. ${ }^{3}$

\section{Table II-North Carolina}

Average Annual Interest Rates Paid On 200 Loans of Different Sizes By White and Negro Borrowers Interviewed in North Carolina, r940

Cash Received
by borrowers

The borrowers in North Carolina, like those in South Carolina. represent varied cases as may be noted from the following:

(I) Mr. A, an employee of a mill for 14 years, receives a salary of $\$ 25$ a week. Because of the sickness of his wife and three children 2 Mr. A borrowed $\$ 55$ in sums of $\$ 5$, $\$ 10, \$ 20$, and $\$ 20$ from four different loan companies. After paying $\$ 69.40$ in interest charges in one year he still owed the original sum of $\$ 55$.

\footnotetext{
${ }^{3}$ For information based on interviews with $\mathrm{x,I} 8 \mathrm{r}$ borrowers in North Carolina, see Simpson, The Small Loan Problem in the Carolinas with a Commentary on Regulation in Virginia, to be published in January, I941, by the P C Press, Clinton, South Carolina.
} 
(2) Mr. B, another mill employee for 15 years, earns $\$ 28$ a week. He supports a wife and two children. When his wife was sick three years ago, Mr. B borrowed $\$ 15$ and has regularly paid $\$ 3$ a month interest ever since. He still owes the $\$ 15$ but has paid $\$ 108$ in interest charges.

(3) A few years ago a farmer reported his experience with a loan company to the Duke University Legal Aid Clinic. He borrowed $\$$ roo but actually only received $\$ 65$ and before the loan was retired he had turned over to the loan company $\$ 45$ in cash, 2 cows, I calf, I mule and 9 hogs.

The high rate interest problem is not confined to the Carolinas. Reports from Kansas, Missouri, Oklahoma, Minnesota and Texas reveal similar findings. The Attorney General of Kansas, in 1935, made available to the Research Department of the Kansas Legislative Council, I07 affidavits which he had secured from borrowers. ${ }^{4}$ Of the roy borrowers, 65 had paid more than $600 \%$ interest on loans, while only eight reported paying a rate of less than $100 \%$. A digest of 300 complaints to the Bar Committees of the Kansas City Bar Assaciation and the Lawyers Association of Kansas City, Missouri, shows that on the $\$ 5,848.85$ in loans reported, $\$ 16,128.10$ was paid in interest by the borrowers. The total paid in excess of principal and interest at $8 \%$ was $\$ 9,741.89 .5$

Missouri's neighboring state, Oklahoma, is likewise suffering from high rate lending. Professor Finley Weaver of the University of Oklahoma reveals that the rates charged on 520 loans made in Oklahoma vary from $133 \%$ to $599.9 \% .^{\circ}$ The following table is from Professor Weaver's published work.?

TABLE III-OKLAHOMA

Comparative Rates Paid By White and Negro Borrowers

\begin{tabular}{|c|c|c|c|c|}
\hline \multirow{3}{*}{$\begin{array}{l}\text { Cash Received, } \\
\text { by Borrowers }\end{array}$} & \multicolumn{4}{|c|}{ Number of Loans and Rate Paid By } \\
\hline & \multicolumn{2}{|c|}{ Whites } & \multicolumn{2}{|c|}{ Negroes } \\
\hline & $\begin{array}{l}\text { Number } \\
\text { of Loans }\end{array}$ & $\begin{array}{c}\text { Average } \\
\text { Annual Rate }\end{array}$ & $\begin{array}{l}\text { Number } \\
\text { of Loans }\end{array}$ & $\begin{array}{c}\text { Average } \\
\text { Annual Rate }\end{array}$ \\
\hline \$ro and less & I99 & 316.3 & 34 & 378.5 \\
\hline$I 1.00-20.00$ & 94 & $3 \times 6.0$ & 17 & 364.7 \\
\hline 21.0030 .00 & 87 & 238.2 & 8 & 289.2 \\
\hline $3 r .00-40.00$ & 10 & 188.0 & I & $24 \mathrm{r} .8$ \\
\hline $41.00-50.00$ & 43 & 156.2 & 2 & $x 80.7$ \\
\hline
\end{tabular}

Before the passage of the Uniform Small Loan Act in Minnesota ${ }^{8}$ in 1939 many high rate lenders operated within the state. In an investigation conducted by the Minneapolis Legal Aid Society in 1937 a total of 307 loans made by 208 borrowers were studied. The average interest rate on these loans was about $224 \%$ per annum, with some exceeding $1000 \%{ }^{\circ}$ The investigation conducted by the Better Business

- See Kans. Legis. Council, The Loan Shark Problem in Kansas (Nov. 1935) 10.

${ }^{8}$ Gisler and Birkhead, Salary Buying in Kansas City, Missouri (1938), Appendix C, Table 2.

- Weaver, Oklahoma's Small Loan Problem (1938) 3r.

TId. at 33 (Table VII).

Laws 1939, c. 12.

- Bachelder, The Small Loan Business Unregulated (Sept. 1939) 205 Anwars 35. 
Bureau of Minneapolis, which extended through the period from July r, I938 to July I, 1939, concerned $4 \mathrm{I} 4$ people and 2,784 loans. The annual interest rate charged varied from $33 \%$ to $\mathrm{I}, 353 \%$. The average interest rate per loan without considering pyramids or renewals was $218.42 \%$ annually. ${ }^{10}$

A decision handed down by the Supreme Court of Minnesota on May 26, 1939, contains statistics which lend general support to the accuracy of the findings of the above mentioned organizations. A district court appointed a receiver to impound the notes and documents of a loan company in Minneapolis. The following is a quotation from the decision of the Supreme Court showing the findings of the receiver after examination of the records of the loan company. ${ }^{11}$

"From examination of the books and evidences of indebtedness of defendant's (Metro Loan Company) business, taken over when appointed, the receiver makes an affidavit showing the existence of 595 loans, upon which there still appears unpaid in excess of $\$ \mathrm{r}_{4}, 000$, although of the total sums loaned of $\$ 14,400$, over $\$ 20,000$ has been repaid. It is further shown that of these loans only four were $\$ 100$ each, all the rest were in sums of $\$ 50$ and less. The interest rate on each loan is shown. Only in five cases was it less than roo per cent per annum. These five were $76,82,87,94$ and 96 per cent per annum. In the other 590 loans the interest rate per annum would average well over 300 per cent, one exceeding 1000 per cent."

The Better Business Bureau in Dallas, Texas, as in Minneapolis, found tha exorbitant rates of interest were being charged. Within a ten-week period $\mathrm{r}, 000$ complaints involving 2,554 loans, totaling $\$ 55,767.23$, made with 72 lending companies were filed with the Better Business Bureau of Dallas. The annual interest rates charged ${ }^{12}$ ranged from $120 \%$ to $113 \mathrm{I} .4 \%$ with an average rate of $271.68 \%$.

It may be noted that studies made of the small loan problem in the Carolinas, Kansas, Missouri, Oklahoma, Minnesota and Texas uniformly reveal the fact that a vast number of the residents of those states have been burdened with immense interest charges levied by unregulated lenders. Perhaps this serious problem may be solved as the people of Minnesota hoped it would be when its legislature passed the Uniform Small Loan Act in I939. Missouri's small loan law was made more effective by its legislature's approval of several amendments in 1939 but unfortunately in the Carolinas, Kansas, Oklahoma and Texas opposition has been sufficient to defeat legislation which would relieve the plight of the borrowers of small amounts.

\footnotetext{
${ }^{10}$ Better Business Bureau of Minneapolis. Special Report on Investigation of High Rate Loan Companies in Minneapolis (1939).

${ }^{11}$ State ex rel. Goff v. O'Neill, 205 Minn. 366, 374, 286 N. W. 316, 320́ (1939).

${ }^{13}$ Better Business Bureau of Dallas, The Dallas Loan Shark Fight (1938).
} 